\title{
Public Sector Unions and Privatization: \\ Evidence from the Eldercare Sector in Danish Municipalities
}

\begin{abstract}
Privatization varies considerably among local governments. One of the oft-listed explanations is the ability of public employees to block privatization. However, many studies on the influence of public employees on privatization do not use very precise measures of the influence of public employees, they have been unable to isolate a one-way effect, and the studies have not been attentive to whether the effect varies for different market forms. In this article, we focus on privatization in Denmark through a voucher market without price competition for eldercare services. Using new data for all 98 Danish municipalities in 2012, we are able to measure the strength of the public eldercare union as well as the number of the public eldercare workers relative to the number of local voters. We find that the increased union strength measured in terms of union density at the municipal level leads to substantially and significantly less privatization through the voucher market. By comparison, the estimated relationship between the relative number of public workers and privatization does not reach statistical significance. Features of the voucher market and qualitative evidence suggest that the union influence primarily goes through a direct user channel, that is through union influence directed at the service users, while a minor effect possibly runs through a political channel, that is lobbying directed at the local politicians.
\end{abstract}




\section{INTRODUCTION}

With the exception of a brief period in the 1980s, the influence of public employees and their unions on public policy has generally been an understudied subject in political science and economics (Anzia and Moe 2015). This is also the case regarding the literature on local government privatization, where one would expect public employees and their unions to have particularly strong preferences (Boyne 1998; Vrangbæk et al. 2015). The privatization literature has long acknowledged the potential importance of public employees and their unions for marketization, but the literature has failed to address the issue convincingly for theoretical and methodological reasons (Boyne 1998; Jalette and Hebdon 2012). Particularly in Europe, the effect of public employees on privatization has received remarkably little attention. As indicated, a literature review from 2007 found that only one quantitative European study had examined public employees with an indicator that was not by definition endogenous to privatization (Bel and Fageda 2007, 526). This lack of research on the relationship between special interest groups and privatization is noteworthy since variation in privatization across policy areas could be due to differences in the political influence of special interest groups (Foged 2015a; Petersen et al. 2015). Moreover, the drivers of privatization, such as interest groups, possibly vary for different market types, such as voucher markets and contracting out (Bel et al. 2014; Hefetz and Warner 2012; Lowery 1998).

This paper focuses on a specific market type in the form of a voucher market, a so-called free choice market, for elderly home care services financed and provided by Danish municipalities. It is a policy area with a great potential for privatization and considerable variation among localities (Petersen and Hjelmar 2014). By using new data on union density for the dominant union for 
public eldercare workers together with data for the number of these workers relative to the number of local voters, we are able to measure the effect of public employees on privatization.

The paper contributes to the existing research by, firstly, integrating the privatization literature with the literature on public sector unions as a special interest group. Second, the paper offers methodological and theoretical improvements to the existing research by using more precise measures of the influence of public employees and by building and testing a theoretical model of the relationship between public employees and privatization through a voucher market. The outline

of this paper is as follows; first, we review the literature on privatization and the effect of special interest groups on public policy. This leads to our theoretical model and hypotheses. Section three describes the case of eldercare services in Danish municipalities and presents the data. Section four contains the econometric tests and the qualitative evidence gathered through the interviews. Section five concludes and discusses the implications of the findings.

\section{LITERATURE REVIEW AND HYPOTHESES}

\subsection{Privatization through a Voucher Market}

Researchers of privatization have often documented that privatization has implications for a wide range of societal concerns, including service costs, service quality, segregation, and working conditions (Böhlmark and Lindahl 2007; Domberger and Jensen 1997; Hodge 1998; Sandström and Bergström 2005; Stolt et al. 2011; Vrangbæk et al. 2015). Given these consequences of privatization, many scholars have also directed attention to the politics of privatization in an attempt to understand the drivers behind the use of private suppliers (Bel et al. 2014; Bel and Fageda 2009; Boyne 1998; Girth et al. 2012; Hebdon and Jalette 2008; Hefetz and Warner 2012; 
Levin and Tadelis 2010). By privatization we mean the various ways public entities can try to structure a market (Warner and Hebdon 2001), in this particular case by allowing private suppliers to compete with one another and the municipal provider in a voucher market without price competition (see section 3.1). Here we use "privatization" synonymously with the private market share.

The article examines the drivers behind the privatization of a well-defined market; a free choice market for elderly home care services. This particular market can be characterized as a voucher market without direct price competition (Bailey 1999; Savas 1987), since the private contractors in the Danish case are paid the long-term production costs of the individual municipality. Instead, the competition between the private contractors and the municipal provider is essentially over service quality.

According to Lowery (1998), although such quasi-markets are typically established to deal with the lack of efficient public production, quasi markets, such as contracting and voucher markets, can themselves be subject to three possible forms of market failures: failure in market formation, failure by preference errors, and failure by preference substitution (Lowery 1998, 141). These potential failures can be present on both the demand and supply sides of the market (Hipp and Warner 2008). Market formation failures involve challenges such as the lack of a sufficient supply of private contractors. Preference error failures involve challenges such as asymmetric information in the relationship between public authorities, contractors, and the ultimate user, while preference substitution failures involve misaligned preferences between the public authority, the user, and the providers. In that context, Lowery (1998) hypothesized that preference error failures could be a particular concern for voucher markets compared to traditional contracting because individual consumers could suffer more from information asymmetries than public authorities with hired 
experts. Due to these information asymmetries, Lowery also noted that the vendors in voucher markets could have particularly strong incentives to engage in the preference manipulation of service users, for instance via intense advertising (Lowery 1998, 151).

The empirical research on voucher markets has thus far focused more on the effects than on the drivers behind them. These voucher market effects have been investigated in areas such as Swedish schools (Böhlmark and Lindahl 2007; Sandström and Bergström 2005), eldercare, child care and the operation of nursing homes in Denmark and Sweden (Petersen and Hjelmar 2014), job training in Germany and the USA (Hipp and Warner 2008), as well as child care in Australia, the Netherlands, and the USA (Warner and Gradus 2011). Besides highlighting the often severe methodological challenges related to data and accounting for service quality and transaction costs in these studies (Petersen and Hjelmar 2014), the evidence reveals a mix of negative and positive effects from a voucher market. The reported negative effects include creaming, reduced service quality, increased transaction costs, and an uneven geographical supply (Hipp and Warner 2008; Warner and Gradus 2011). On the positive side, however, some studies find improved service quality, increased demand among users, and an increase in supply (Böhlmark and Lindahl 2007; Sandström and Bergström 2005; Warner and Gradus 2011).

\subsection{Privatization and Public Employees as a Special Interest Group}

In this paper we argue that the political influence of interest groups, here focusing on public employees, has been understudied in the privatization literature, although interest groups should have explanatory power for differences in privatization. The study of the political effects of public sector unions and public employees on public policy is part of a relatively new but growing literature. Except for a short period in the 1980s, much of the research on public policy variation 
and special interest organizations did not deal with the influence of one group, for which public policy should have the most important consequences, namely public employees and their unions (Anzia and Moe 2015). This lack of scholarly interest is remarkable given that many public policy decisions have direct and influential consequences for public sector employees and the unions representing them. Especially privatization should be a public policy decision of high political salience for both public sector employees and their unions, since privatization should have direct consequences for public employees themselves (Vrangbæk et al. 2015) as well as putting their unions at the risk of losing members to private sector unions or non-organization.

\subsubsection{The Effect of Public Sector Unions on Privatization: Previous Literature}

In acknowledging the potential influence of interest groups, the privatization literature has continuously mentioned interest groups (particularly those representing public employees) among the four main factors behind privatization. The other drivers are fiscal stress, public preferences, and scale and market structures, including public organizations as smart sellers and buyers (Amirkhanyan 2006; Bel and Fageda 2009; Boyne 1998). Among these four factors, the influence of interest groups, public employees in particular, is probably the single factor behind privatization where methodological challenges have done the most to limit the number and quality of studies. Where recent research has seen advances in estimating the effect of ideology (Elinder and Jordahl 2013; Guardiola et al. 2010; Sundell and Lapuente 2012), fiscal stress (Guardiola et al. 2010), and

scale and market characteristics (Foged 2015b; Girth et al. 2012; Hefetz and Warner 2012), the influence of interest groups remains an outstanding issue due to some of the same challenges highlighted by George Boyne more than 15 years ago (Boyne 1998). 
The theoretical and methodological challenges concern the following issues. First, the privatization literature has proposed opposing mechanisms for the relationship between public employees and privatization without resolving the theoretical net impact (Boyne 1998, 157) and without differentiating between the effects and mechanisms for different market types. For once, the possible negative effect of public employees on privatization has been difficult to separate from a supposedly opposite effect due to more favorable working conditions (and in turn higher public production costs) in more unionized municipalities. Furthermore, whether the effect of public employees varies according to the particular market form has not been sufficiently dealt with in the literature. For instance, one might hypothesize that interest groups are particularly important in a voucher market compared to a contracting out market due to greater information asymmetries between the producers and the decision-maker in a voucher market than in a contracting out market (Lowery 1998).

Second, many studies remain susceptible to methodological problems, reverse causality in particular (Bel and Fageda 2007; Boyne 1998, 159). This becomes especially evident in the many studies where the influence of public employees is measured as the ratio of public employees to the number of inhabitants, which per definition is endogenous to privatization (Bel and Fageda 2007).

A minor body of North American studies has carried out pioneering work regarding public sector unions and privatization. These studies have generally highlighted two opposing theoretical mechanisms (Chandler and Feuille 1994; Hirsch and Osborne 2000; Jalette and Hebdon 2012). On the one hand, public employees can use their political clout to block privatization, which ought to be easier if the employees are organized. On the other hand, heavily organized public employees 
should increase public production costs due to more restrictive labor agreements, thereby increasing the public premium of privatization.

Different indicators have been used when accounting for the effect of public employees, including a dummy variable for organized workers (Chandler and Feuille 1994; Jalette and Hebdon 2012; Levin and Tadelis 2010), a dummy variable for the existence of a collective/restrictive labor agreement (Fernandez et al. 2008; Hebdon and Jalette 2008), the perceived opposition to privatization among line employees (Fernandez et al. 2008; Hefetz and Warner 2004), and the union density or number of union branches within a local government (Ferris 1986; Hirsch 1995; Jalette and Hebdon 2012; Warner and Hebdon 2001). The studies with these indicators have produced mixed results, most of them reporting either a negative or no association between public employees and privatization.

Studies finding a negative effect have pointed out the conditional nature of this association, existing only for traditional contracting out and not for other types of restructuring (Levin and Tadelis 2010; Warner and Hebdon 2001) or only under cooperative relations with the municipal decision makers (Chandler and Feuille 1994; Jalette and Hebdon 2012). In contrast, studies finding a positive association have explained this association with the higher financial premium of privatization when public workers are employed under relatively lucrative working agreements (Fernandez et al. 2008). Finally, studies reporting no effect of public employees have seen this as an expression of the two effects cancelling each other out (Hebdon and Jalette 2008; Jalette and Hebdon 2012).

In sum, although the abovementioned studies have been valuable contributions, theoretical and methodological challenges still exist. First, the indicators used for public employees are often 
crude and susceptible to reverse causality. Second, with the two theoretical mechanisms running in different directions and possibly being different for various market forms, it is difficult to identify the separate effects. This article specifically addresses these challenges. The next section describes the previous literature within the area of public sector unions upon which we build our theoretical argument.

\subsubsection{The Effect of Public Employees and their Unions on Public Policy}

In theory, public employees can affect public policy both as individual voters and as union members. As individual voters, public employees should matter for politicians since public workers can hold particularly strong preferences for public policies due to the fact that these policies can directly affect their working conditions. Several Scandinavian studies seem to suggest such a "public sector voter" channel. A study of the electoral behavior in a Danish municipal election finds that public employees tend to vote at a higher propensity than other voters, especially if working in their municipality of residence (Bhatti and Hansen 2013). The authors interpret this finding as public employees using the opportunity to elect their own "employers."

Data from a Norwegian survey also suggests that Norwegian public employees are more sensitive to public sector reform when voting, which should give them status as swing voters and in some models of voting give them more influence as voters (Rattsø and Sørensen 2004). Bonesrønning (2013), trying to assess the consequences of public employees' political preferences, finds that the successful implementation of an educational reform in Norwegian municipalities is negatively associated with the share of public employees in a given municipality. He refers to the ability of public employees to shape school leaders' attitudes towards reform as a potential mechanism. Moreover, in an earlier study on market orientation in Danish municipalities, Christoffersen and 
Paldam (2003) found that municipalities with a larger share of voters who are dependent on either public transfers or public salaries are significantly less market-oriented.

Besides being individual voters, public employees can also organize. Formal organization ${ }^{1}$ through increased unionization helps to pool resources and provides greater mobilization potential and clout when lobbying politicians. So the ability of public sector unions to gain and maintain a high level of union membership would be seen as crucial to their political influence at the local level. In accordance with this view, Campbell and Sances (2013) find that American states with higher public union density were more likely to use tax increases rather than budget cuts when consolidating state finances in the wake of the 2008 financial crisis. Freeman and Han (2012) find tentative evidence that US states with higher public union density and more public sector collective bargaining have higher fiscal deficits and more public debt. In an even newer item of research, Anzia and Moe (2015) survey the influence of public sector unions on US municipalities and argue that unionism and public sector collective bargaining increase municipal spending on wages and benefits for public sector workers. In sum, whereas most studies have looked at union influence on political decisions (political channel), the direct influence on the service users (user channel) has been studied less. Such a user channel could be of particular importance in a voucher market due to greater information asymmetries between the producers and the decision-maker in a voucher market than in a contracting out market.

\subsection{Theoretical Framework and Hypotheses}

\footnotetext{
${ }^{1}$ In the study of special interest groups, this is often thought as "solving the collective action problem" among potential group members with a common interest. This issue has been at the forefront of the research on interest groups, including unions, since Olson (1965).
} 
Building on the abovementioned literatures on privatization and special interest politics, we expect special interest groups within the area of public service provision, such as public sector unions, to have large stakes in privatization and often to hold other and more intense preferences than the general voter. This expectation builds on the assumption that the organizations' resources ${ }^{2}$ and the welfare of their members depend more on the structure of public service provision, including the level of privatization, than the general voter. For instance, where the impact of privatization on price and quality can be diffused for the general voter, the organizational resources of public unions and the general working conditions of its members can experience concentrated implications of privatization (Olson 1965; Vrangbæk et al. 2015). Similarly, in addition to being opposed to privatization as union members, public employees can also oppose privatization as individual voters due to self-interest and ideological convictions (see 2.3.2).

How does the relationship between public employees and their unions on the one hand and privatization on the other hand look like for a voucher market? For the relationship between public unions and privatization we hypothesize that a voucher market reinforces a negative association between the two. This is due to the expectation that union lobbying directed at the service users can be particularly effective due to high information asymmetries between producers and users and because the ability for local politicians to influence the level of privatization (and therefore reap potential cost savings in heavily unionized localities) can be limited for voucher markets where the service user makes the final producer choice. The magnitude of such a negative relationship between union strength and privatization of cause, in turn, depend on the specific

\footnotetext{
${ }^{2}$ As previously argued, increased privatization might increase a public sector union's risk of losing members to nonorganization or private sector unions.
} 
features of the voucher market such as whether or not a price competition exist and the ability for local politicians to determine local market conditions (see section 3.1). For the relationship between public employees as individual voters and privatization we also expect a negative association to be present for a voucher market, at least to the extent that local politicians are able to affect local privatization.

In addition to differentiating between public employees as individual voters and union members, we propose a theoretical model with two channels of influence: a user channel and a political channel (see Figure 1). We argue that the user channel will generally be particularly important in a voucher market and probably more important than the political channel, since the user is ultimately making the choice (Lowery 1998). To stress this hypothesized importance of the user channel over the political channel, the political channel is illustrated with a dashed line in Figure 1.

[Figure 1 around here]

\subsubsection{Hypothesis I: Public Employees as Union Members}

The theoretical mechanism of the effect of public unions is outlined in Figure 1. The hypothesis is that public union strength potentially affects the level of privatization through a user channel and a political channel. The user channel should work through general local opinion formation, such as formal and informal advertising, and, when possible, though direct interaction between public union members and the service users, such as direct contact through function testing and service delivery. Such a user channel was already proposed by Lowery (1998), albeit while focusing less on public unions than on the direct influence of private contractors on the service users. 
In the presence of a better organized local workforce, local union activists can therefore mobilize local workers against private contractors more easily, as they have better access to contact information and unionized personnel are more likely to attend union-organized meetings and events (Iversen and Soskice 2015). ${ }^{3}$ This in turn causes more public workers to provide a negative image of private contractors when performing their jobs.

Besides the user channel, public unions can also influence local politicians (Anzia and Moe 2015; Campbell and Sances 2013; Freeman and Han 2012). Although these politicians do not make the final production choice in the case of a voucher market, they can in theory still affect the conditions for private contracting within the jurisdiction. Depending on the specific market regulation, local politicians can directly or by influencing the local administration set various approval and quality requirements pertaining to private vendors; they can influence the level of administrative burdens for private contractors in general, rendering it more or less easy for private contractors to operate; and they can influence the general level of information they provide to the potential users about the opportunity to use private contractors. Furthermore, local politicians can directly try to influence the local public opinion about the use of private contractors.

When influencing local politicians, increasing the local unionization empowers local union activists and leaders with greater financial resources and - and perhaps more importantly - a more powerful argument in favor of them "representing" the local workers. This gives union activists and formal leaders more clout when lobbying municipal politicians. Furthermore, greater local

\footnotetext{
${ }^{3}$ This mobilization effect of union membership is prevalent in the general and comparative study of the politicaleconomic effect of unionization; see Iversen and Soskice (2015) for an example.
} 
union capacity makes it easier to mobilize the public workers to protest and/or petition against initiatives, which could increase privatization. In sum, we hypothesize that:

- $H_{1}:$ A greater union strength among affected public employees negatively affects the level of privatization in a voucher market.

\subsubsection{Hypothesis II: Public Employees as Individual Voters}

Another potential effect of public workers on privatization is through a more pure voting channel. We simply hypothesize that the political clout of the affected public workers should increase with their vote share and we assume that they will be opposed to privatization both out of self-interest and ideological convictions. The pure self-interest channel relates to job security considerations, since affected public sector workers would face at least perceivably less job security under privatization as well as the overall assumption that public sector workers are generally harmed, at least in the short run, by increased privatization (Vrangbæk et al. 2015).

On the purely ideological side, we simply assume that public sector workers hold more pro-public sector views in line with previous research on the political attitudes of public sector employees (Jensen et al. 2009; Tepe 2012), which would lead them to prefer public as opposed to private production and accordingly to oppose privatization. Thus, a larger share of the affected public workers in the electorate could make local politicians cautious in terms of creating favorable conditions for private contracting, at least to the extent that the local politicians can affect these conditions. In sum, we hypothesize that:

- $H_{2}:$ A greater share of affected public workers to all voters negatively affects the level of privatization in a voucher market. 


\section{DATA AND RESEARCH METHODS}

\subsection{The Voucher Market for Eldercare Services in Danish Municipalities}

\subsubsection{The 2003 Reform and Private Market Share}

Our case for testing the effect of public sector unions and public employees on privatization is eldercare in Danish municipalities, which is a low-wage service area. Both in terms of those employed and the share of the municipal budget, eldercare is the single largest publicly financed social service at the municipal level in Denmark. The observed privatization within the Danish eldercare area consists mainly of the privatization of home care services through a voucher market. This free choice market for elderly home care services was introduced from the "outside" by the national government in 2003 (Bækgaard 2011, 3; Rostgaard 2006). The 2003 reform brought about a comprehensive reorganization of the municipal home care services, instructing the municipalities to make an internal organizational division between approval/supervision on the one hand and service delivery unit(s) on the other. Besides giving the elderly a free choice, the reform was intended to encourage cost-efficient production (Foged and Houlberg 2015).

The 2003 reform also greatly reduced the influence of local politicians over privatization. Not only did they have to hand over final decision-making to the users, the approval of private contractors also became a highly administrative issue, where private contractors almost automatically had to be approved if they conformed with local quality requirements (Foged and Houlberg 2015). The dominating voucher scheme did not introduce price competition, as each municipality had to pay the private contractors the municipality's own long-term production costs. Consequently, Danish municipalities could set their own quality standards, equivalent to a certain price, and private 
contractors could seek local approval under these conditions. The service users could then freely choose between all of the approved contractors in the municipality, private and municipal alike (Bækgaard 2011).

These specific market characteristics of the Danish home care services favor the observation of a one-way effect from the opposition of public employees on privatization though the user channel for three reasons: First, by looking at a free choice market imposed from the outside by the national government as late as 2003 , it seems plausible that differences in the clout of public employees and their union, which by 2003 were long established in the municipalities (FOA 2015b), affected the local success of private contractors - not the other way around. Second, the reduction of the influence of local politicians on privatization due to the 2003 reform should make the user channel dominate the political channel even more than should already be the case for voucher markets. Finally, in addition to the diminished influence of local politicians, the absence of direct price competition excludes opposing economic incentives for privatization, because the introduction of private contractors does not directly affect the municipal production costs (see section 2.1).

The free choice for home care services pertains to three types of services in the form of practical help such as cleaning, washing of clothes, and shopping, more complex personal care such as personal hygiene, and finally food services. The largest of these service areas is practical help and personal care, where the largest private market share exists for the relatively simple practical help services (Foged and Houlberg 2015). For practical help in particular, the market share of private producers gradually increased after 2003, and a structural reform in 2007 that reduced the number of municipalities from 271 to 98 seemed to support this consolidation of the private market (Foged and Houlberg 2015). Thus, one year after the implementation of free choice in 2004, $10 \%$ of the home care receivers opted for a private contractor, a figure that had increased to $46 \%$ in 2013. For 
more complex personal services, the private market share also increased, although more slowly, meaning that the private market share increased from 1\% in 2004 to 7\% in 2013 (Bækgaard 2011, 13-14; Foged and Houlberg 2015, 21). In the observed year of 2012, the average municipality contracted out $19 \%$ of all eldercare services (see Table 1). Moreover, the private market increase seemed to be supported by a parallel jump in demand due to the growing number of elderly.

\subsubsection{Public Eldercare Workers and their Union}

We expect the relatively rapid implementation of a private free choice market to have affected the public employees in municipal eldercare as well as the position of their union, FOA (Trade and Work). FOA is the third largest union in Denmark and the largest "public" union, counting almost 200,000 essentially public sector workers. Among others, FOA organizes the social and health care workers, who care for the elderly and, together with the municipal employer organization, Local Government Denmark (LGDK), FOA negotiates the collective bargaining agreement that applies to all municipalities. In principle, FOA can also negotiate agreements with private contractors, but of the 480 approved private contractors in 2013, FOA had agreements with only 70 suppliers (FOA 2013b). In this way, it is easy to see why FOA would oppose a free choice market, since a private market almost automatically reduces the share of eldercare workers employed under FOA's collective agreement. A drop in the number of FOA members reduces not only the number of paying members but also FOA's bargaining potential. Thus, private eldercare workers are usually members of a private union or non-organized.

Consequently, it comes as no surprise that FOA has opposed the free choice market for eldercare services ever since its introduction in 2003. For instance, FOA has conducted national and local campaigns to point out supposedly low service quality or poor working conditions among private 
contractors and directed efforts to get local private contractors to sign working agreements with FOA (FOA 2013a, 2013b, 2015a). For every municipality, FOA has a senior shop steward that organizes local activities and is supported by 42 regional offices.

\subsection{Data and Operationalization}

\subsubsection{Data Sources}

The hypotheses are mainly tested on register data from Statistics Denmark, The Ministry of Economics and the Interior, The Municipalities' and Counties' Salary Data Office and FOA. One would preferably have data from several years, but since the union variable is only available for October 2012, only data from this year is examined. The limitations of the cross-sectional data are offset, however, by the accurate nature of the union variable not previously having been used in the Danish - and only rarely in the international - context. The quantitative data is also supported by interviews with representatives from FOA's national branch in order to understand the possible channels of union influence within eldercare.

Moreover, interviews were conducted with mayors from five different municipalities in 2014. These mayors were selected on the basis of the level of privatization across all policy sectors in 2008 and the change in this privatization from 2008 to 2012 so that mayors from municipalities with high/increasing (two mayors), high/decreasing, low/increasing, and low/decreasing privatization were interviewed. The mayors were asked what they generally considered to be the main drivers behind privatization, including the relative importance of different drivers, such as economic situation, ideology, and interest group influence, the latter referring for example to FOA's importance within home care for the elderly. Since the local features of the main independent variables, related to the features of the local eldercare workers and the local union 
strength, were not known in advance, the interviews could be used to investigate the expected negative relationship between public employees and their unions on privatization (King et al. 1994).

\subsubsection{Operationalization of Variables}

The level of privatization is measured as the percentage share of services within eldercare provided by private contractors, registered in the municipal accounts (Petersen et al. 2015). Union strength is measured in terms of the number of eldercare workers working for the municipality and being members of FOA as a share of all municipal eldercare workers. This variable, which is normally not possible to identify this accurately, is provided by FOA for 2012 as an index in which the national average is 100 .

The employee variable is measured in two ways. First, "municipal eldercare workers" is measured as a share of the eligible voters in the municipality. ${ }^{4}$ Although very precise in accounting for the proposed theoretical mechanism, the employee variable is naturally endogenous to privatization, since higher privatization by definition reduces the number of public employees (Bel and Fageda 2007).

Another indicator, which should be considerable less endogenous, is therefore used in the form of local spending on the elderly as a share of total operating expenditures. This variable should capture the number of eldercare workers in proportion to all municipal employees and at the same time not be (importantly) endogenous to privatization, because the degree of privatization should not affect the elderly spending, as the financing is still public and the payment to private

\footnotetext{
${ }^{4}$ This variable is not collinear with union density with a pearson's $r$ of 0.42 .
} 
contractors accurately reflects the municipality's own production costs (see section 3.1). The level of privatization could of course affect costs through indirect mechanisms such as transaction costs, a change in municipal production scale and municipal attention to costs, but a recent study shows that the level of privatization in Danish home care is only related to production costs for the relatively small service area within eldercare, practical help services, where more privatization is expected to increase prices (Foged and Houlberg 2015). Since this positive effect is substantially small and practical help services only constitute around $15 \%$ of the total elderly spending, this endogeneity can at most introduce a weak conservative bias in the expected negative association between elderly spending and privatization.

The control variables are guided by theory and existing research pointing to the possibly confounding effect of fiscal stress, scale and market structures, and the political preferences of local citizens and politicians. Fiscal stress is operationalized as the ratio between the municipalities' objective expenditure need and the tax base after financial equalization among the municipalities. ${ }^{5}$ We expect fiscal stress to be positively correlated with privatization in a free choice market, since the contractors' opportunity for profit can be better in these affluent localities due to higher service levels, higher prices, and higher demand (Foged 2015a, 28). Accounting for scale and market structure, the number of elderly over age 65 as well as the geographical distances

\footnotetext{
5 "Objective expenditure need" is calculated by the government based on the social and demographic characteristics of each municipality. Together with the tax base (at an average tax rate), this calculation is used as the basis for the extent of intergovernmental aid to each municipality. In practice, the local governments have a balanced budget requirement so that expenditures equal revenue. This requirement, as well as the fact that the intergovernmental grant system only removes some of the economic differences between municipalities, means that less affluent municipalities must set lower service levels than more affluent localities.
} 
in the municipality are included in order to control for economies of scale affecting both the production function for the municipality and the private provider (Andrews 2013; Bel 2013; Bel and Fageda 2009; Foged 2015b; Warner 2013). Furthermore, variables are included for small islands and large cities in which special production conditions might exist.

With respect to political preferences and ideology, the share of left-wing municipal council mandates is used as an indicator. Normally, we expect left-wing parties to block privatization (Elinder and Jordahl 2013; Sundell and Lapuente 2012). When observing a free choice market without price competition, however, we do not expect ideology to play a large role (Foged 2015a). By controlling for local political preferences, we thus seek to isolate the hypothesized officeseeking effect of local politicians through the political channel, although this effect is hypothesized to be small (see section 3.1). Left-wing parties are operationalized as the Social Democrats, the Socialist People's Party and the Red-Green Alliance. For various reasons, the local party composition may not accurately capture the citizens' political preferences and we therefore include the share of left-wing parties in the 2011 national elections as an alternative, and possibly more precise, indicator of local preferences. Finally, to account for a possible effect of the structural reform of Danish municipalities in 2007, a dummy for the municipalities amalgamated in 2007 is also included. A full list of variables and summary statistics is presented in Table 1.

[Table 1 around here]

\subsection{Econometric Approach}


To estimate the effect of union density and public eldercare employees' vote share on privatization, we use multiple regression estimated with OLS and robust standard errors. The estimated regression model is:

Privatization $_{i}=\beta_{0}+\beta_{1}$ union strength $h_{i}+\beta_{2}$ vote share ofpublic elderly employees ${ }_{i}+$

$$
\beta_{4} \text { controls }_{i}+\varepsilon_{i} \text {, }
$$

where Privatization $_{i}$ is the private market share and union strength $_{i}$ is the union density of the municipal eldercare workers. The vote share ofpublic elderly employees en $_{i}$ is the share of elderly spending relative to the total operating expenditures as well as the number of municipal eldercare workers as the share of all eligible voters. Controls ${ }_{i}$ is a vector of included control variables.

The main challenges to identifying the causal effect are omitted variables and reverse causality. First, in addition to the inclusion of control variables, the challenge from possibly omitted variables is addressed by examining a voucher market with favorable conditions for identification. These market conditions make the political channel less possible and remove possible differences in municipal privatization premiums, since the introduction of private contractors does not affect municipal production costs (see section 3.1). Likewise, the market form should also improve the possibility for holding interaction effects constant with other special interest groups, since public employees should be the single most affected group by free choice. Hence, service users, and tax payers in general, do not normally oppose the expansion of their provider choice, which is often in contrast to other types of privatization, where public employees and their unions can seek alliances with user groups fearing reduced service quality (Christoffersen and Paldam 2003). 
Second, the challenge from the possibility of reverse causality is addressed through the research design and by using an instrumental variable. Reverse causality can be an issue if, for instance, unionization drops among public employees after privatization (Chandler and Feuille 1991) or if an overrepresentation of non-unionized public workers shifts to a private employer in the case of privatization, leaving the union density higher in the public sector. By studying a free choice market imposed from the "outside" by the national government in 2003, where the local clout of public employees and their union was already established, it seems more likely that the public employees affected the success of private contractors than the other way around. As a further means of controlling for possible reverse causality, however, we conduct a robustness test using an instrumental variable approach (see supplemental material, Appendix 3). As an instrument we use average (weighted) union density in the neighboring municipalities. By using this variable as an instrument, we seek to exploit union density in the neighboring municipalities being correlated with unionization in the observed municipality due to job rotation across municipal borders, while union density in neighboring municipalities should in theory not affect the privatization rate in the municipality.

\section{RESULTS}

\subsection{Main Results}

\subsubsection{Hypothesis I: Public Employees as Union Members}

Table 2 presents our main results. In models 1-6, we test Hypothesis I, regarding the effect of union strength, while models $7-8$ test Hypothesis II about the effect of the number of eldercare workers relative to municipal voters. 
In model 1, we present a simple bivariate regression between unionization and privatization. In this specification, the union density for local eldercare workers shows a statistically strong, negative association with the share of eldercare privatization. The effect is arguably of a non-trivial size, with a one standard deviation increase in local eldercare union density being associated with a 3.6 percentage point decrease in eldercare being contracted out. In column 2, we add the fiscal stress variable. In this specification, the effect size of local union density drops, but only slightly, and the variable remains statistically significant at the $\mathrm{P}<0.05$ level. Columns 3 and 4 control for scale and market structure, which also does not influence the effect size and significance of the union variable substantially. Finally, in the main specification, model 5, we control for the effect of the party composition of the local council and the amalgamation in 2007. In this specification, the local union density variable remains statistically significant at the $\mathrm{P}<0.05$ level and even increases in effect size so that a one standard deviation increase in unionization is expected to reduce privatization by 3 percentage points. This is equivalent to a $16 \%$ decrease in privatization when compared with the national average privatization level of $19 \%$ in 2012. As seen in model 6, it makes no substantial difference when we control for local public preferences via left-wing votes in the latest national election instead of the party composition in the local council.

Together, the variables in the preferred model 5 explain $25 \%$ of the variation in privatization across the municipalities, which is a goodness of fit similar to other studies of privatization in Danish municipalities (Bhatti et al. 2009; Petersen et al. 2015). Taken together, the results strongly support Hypothesis I, that the union strength of the affected public employees reduces privatization though a voucher market. Given the specific features of the Danish home care voucher market, it is hypothesized that this effect should first and foremost go through the user channel. 


\subsubsection{Hypothesis II: Public Employees as Individual Voters}

Models 7 and 8 test Hypothesis II by adding two different indicators. As expected, model 7 finds that the share of municipal eldercare workers to the local number of voters is correlated with significantly less privatization. Consequently, a one standard deviation increase in the vote share

of publically employed eldercare workers reduces privatization by 4.2 percentage points. This association is unsurprising given the endogenous nature of the indicator and we therefore test for the effect in model 8 with the alternative measure in the form of eldercare spending as a share of total operating spending. With this indicator, the effect decreases and is no longer statistically significant at conventional significance levels. The coefficient (which could be slightly conservative, as explained in section 3.2.1) remains negative, however, indicating that, as expected, there can be a slightly negative effect on privatization. In sum, the evidence from model 8 means that Hypothesis II is not supported in statistical terms but that a small negative effect cannot be ruled out. This absent or modest effect of the relative number of municipal eldercare workers on privatization does not seem surprising given the observed voucher market, where the importance of the political channel should be limited.

Both in models 7 and 8 , the union density variable remains of a substantial size and retains its statistical significance.

[Table 2 around here]

\subsubsection{Control Variables}

We choose to report the control variables based on model 5 in Table 2. These control variables generally show the patterns expected for the Danish context. Contrary to most international studies (Guardiola et al. 2010), fiscal stress is associated with significantly less privatization, which is not 
a surprising finding for Danish municipalities in general (Bhatti et al. 2009; Pallesen 2004) and for free choice markets in particular (Foged 2015a). Thus, private contractors can be expected to be attracted by markets with high earnings potential, such as affluent municipalities (where service levels and therefore payments to private contractors are often higher and where elderly are more disposed to buy add-on services) and localities with increasing demand.

Regarding scale and market structure, model 5 indicates that the privatization of elderly services is more pronounced in municipalities with relatively few elderly and large geographical distances. Although not very robust to alternative specifications, this finding could indicate that markets with few elderly and great distances are easier to access for private contractors due to less competition.

While neither small islands, cities, nor amalgamated municipalities have a significant effect on privatization (although the direction of the coefficients are as expected), model 5 implies a rather surprising, weakly significant, positive association between the share of left-wing mandates and privatization. While this association is weak and not very robust to alternative specifications (see, e.g., columns 7 and 8), it still indicates that free choice markets are less an ideological matter than contracting out markets. Moreover, the findings possibly suggest that while local politicians possibly have ideological objections to privatization to a voucher market, their ability to influence this choice through the political channel is limited.

\subsection{Further Evidence on the Effect of Union Strength}

\subsubsection{Robustness Tests and the Test of Market Assumptions}

In this section, we conduct a number of robustness tests in order to test the validity of the support we found for Hypothesis I regarding the effect of unionization on the private market share. In 
contrast, we do not conduct further tests of Hypothesis II due to the methodological challenges with one of the indicators (municipal eldercare workers relative to the number of voters) as well as the insignificant result with the other measure (elderly spending as a share of total spending).

The online supplemental material, Appendix 2, presents these checks for robustness and tests of market assumptions. The robustness tests show that the effect of union strength on privatization does not change when adding other possible confounders from the literature. Thus, neither the municipal organization of the home care area nor regional differences/learning effects seem to influence the impact of the unions on privatization (Appendix 2, models 1 and 2). Moreover, controlling for the number of private contractors, regardless of the indicator used, makes no difference for the relationship between unionization and privatization (Appendix 2, models 3 and 4).

In addition to these robustness tests, we test whether the free choice market for eldercare behaves as assumed. This seems to be the case from the tests in Appendix 2, models 5-7. First, as expected, union strength does not directly influence the municipal costs and with them the municipal economic incentives to expand the private market share (Appendix 2, model 5). Second, the number of private contractors does not seem to influence the union density, indicating that unionization is not endogenous to privatization, as assumed (Appendix 2, model 6). Finally, the elderly vote share also turns out to be unrelated to privatization, which suggests that, as expected, we are able to hold possible interaction effects with other interest groups constant since the service users do not seem to oppose free choice (Appendix 2, model 7).

As a further test of the causal claim and in order to deal with the question of reverse causality and general endogeneity, we conduct an instrumental variable regression using the average (weighted) 
union density in the neighboring municipalities as the instrument. The results are found in the online supplemental material, Appendix 3. Although the exogeneity assumption of the instrumental variable regression can be questioned (see discussion in Appendix 3), these tests indicate support for the validity of the link between eldercare workers' union density and the level of privatization, since the effect size increases. The increase in the effect size can possibly be due to the instrumental variable removing a tendency for less unionized workers to be the first to leave their municipal employer in the case of increased privatization.

\subsubsection{Qualitative Evidence of the Mechanism}

The negative effect of union strength on the private market share is also supported by interviews with representatives from FOA and with the five mayors. These interviews show that FOA actually regards their local influence on eldercare production as bigger under free choice schemes than under traditional contracting out because, according to FOA, the free choice market is less a local ideological matter.

According to FOA, local union influence in the home care market can go through both user and political channels, the user channel supposedly being the most important. An important role in this respect is assigned to the senior shop steward in each municipality and their ability to mobilize municipal employees and connect with local politicians. Almost all 98 municipalities have such a senior shop steward who receives a five-week training program at FOA's national branch. According to FOA, the charisma and enterprise of this shop steward normally has great influence on local unionization and activity.

With respect to the user channel, the FOA representatives sketch out the following mechanism: In heavily unionized municipalities, professional norms and perceptions of the municipal service as 
being superior to the private alternatives are often more pronounced than in local governments with less unionization. According to FOA, these norms can then be passed on from the unionized social and health assistants to the elderly service users in the course of their daily interaction. If the elderly individual and their relatives are satisfied with the municipal service, they will be less inclined to shift to a private supplier. Further along these lines, it is also possible that the assessments officer, who is normally also a FOA member, plays a role for the elderly individual's decision by presenting them with different producer alternatives.

In sum, FOA regards the user channel as important both before and after the first user choice. Before the first choice, the local union can influence service users through direct interaction in a potentially interim period until an official supplier choice is made, through the assessment officer's presentation of alternative providers, and finally by influencing the local reputation of providers. Moreover, after the first choice is made, the local union can influence the choice-makers by convincing them to continue with the municipal provider and encouraging them to also choose the municipal provider if they, as a consequence of deteriorating health, are referred to more services. In the case where the elderly individual chooses a private supplier and does not interact with unionized eldercare workers in other circumstances, this influence via direct interaction ceases to exist.

In conclusion, FOA's statements support an interpretation whereby the union's effect on privatization predominantly goes through the user channel. These statements seem to echo Lowery's (1998) suggestion that special interest groups can be more influential in a voucher market than for traditional contracting due to greater information asymmetries between the producers and decision-makers in a voucher market. Where Lowery seemed to focus on private sector interest groups, this article reveals how the argument also holds for public interest groups. 
Although regarded as less important than the user channel, FOA does not rule out that some union influence can go through a political channel, since union activism can push local media and politicians to be sensitive to the service quality and working conditions among private firms. That a minor share of the union influence can go through the political channel is also tentatively supported by the interviews with the mayors. According to them, considerations about municipal employees and their unions generally play an important role in local privatization decisions, although the influence is less important and direct for free choice markets. These considerations regard both political costs for local councilors related to employee opposition towards privatization as well as a sense of responsibility deriving from the position of the politicians as employer. With respect to free choice and home care, one right-wing mayor expresses how politicians, regardless of the market form, can still influence the conditions for private contracting and how this effort can be affected by the local FOA union:

"We would like to market our free choice pertaining to eldercare much better, but as politicians we experience opposition from the employees and their unions. The national union, and in particular the strength of the local union branch, is important."

\section{DISCUSSION AND CONCLUSION}

\subsection{Main Findings}

Privatization and various types of contracting out vary significantly among sub-national political units. One of the oft-listed explanations for these differences is the variation in the political influence of public sector workers and their unions. However, most of the studies that try to assess 
this claim suffer empirically from imprecise and endogenous proxies for the potential influence of public sector workers and their unions and are often unable to distinguish the effect from a supposedly larger economic incentive for local governments to contract out in high-unionization localities. Furthermore, little attention has been devoted to how the potential effect differs for different market types.

This paper has focused on privatization through a voucher market for eldercare in Danish municipalities. Using new data, we are able to measure the local union's organizational capacity for Danish public eldercare workers at the service area level. Besides an improved measure for organizational capacity, the observed free choice market without price competition offers favorable conditions for identifying an effect of public employees on privatization, primarily through a user channel (union influence directed at the service users) and possibly also through a political channel (lobbying directed at the local politicians). Thus, the specific voucher market was introduced from the "outside" by the national government, and any municipal economic incentives to expand the private market were reduced by the absence of direct price competition.

Against this background, our results show a statistically significant, negative association between the organizational capacity of the dominant eldercare union and the level of privatization within eldercare. In the preferred model 5 in Table 2, a one standard deviation increase in union density is expected to reduce the private market share by 3 percentage points. This is equivalent to a $16 \%$ decrease in privatization when seen in proportion to the national average privatization level of $19 \%$ in 2012. This effect of local unionization is robust to various controls, retains explanatory power with an instrumental variable estimation, and is supported by qualitative evidence. Taken together, this suggests that the relationship is causal. 
Besides the influence of union strength, a negative association is also observed between municipal eldercare workers as a share of municipal voters and privatization. However, this association does not reach significance with the alternative, considerably less endogenous indicator. In sum, the paper finds a robust negative relationship between union strength and privatization, while an influence from the relative number of municipal eldercare workers can neither be supported nor rejected.

Further qualitative evidence on the relationship between union strength and privatization supports the expectation that the estimated effect primarily runs through the user channel, with a modest effect possibly also running through the political channel.

\subsection{Discussion of Findings}

This paper contributes to a growing literature on the influence of interest organizations, especially public employees and their unions, on public policy in general and privatization in particular. From the perspective of the privatization literature, the study reveals the importance of interest groups on privatization. For theoretical and methodological reasons, interest groups have been understudied in the literature despite both theory and empirical evidence highlighting how special interest groups can account for variation in privatization across municipalities and across policy areas (Foged 2015a). The influence of interest groups should therefore be regarded as an important privatization driver, juxtaposing factors such as market characteristics (Hefetz and Warner 2012) and service characteristics (Brown and Potoski 2003; Shrestha and Feiock 2011). 
Secondly, the study shows the importance of distinguishing between different market types (Bel et al. 2014), where variation can teach researchers much about the drivers behind privatization, since some factors are probably more important for some market forms and service areas (Girth et al. 2012; Hefetz and Warner 2012; Jalette and Hebdon 2012; Warner and Hebdon 2001). The evidence from the Danish case suggests that interest groups can be more important for voucher markets than for traditional contracting out, since the information asymmetry between the decision-maker and provider can be greater for voucher markets. This could involve both stronger influence from the relevant private providers (Lowery 1998) as well as the affected public workers' union. In other words, where the purpose of a voucher market can be a way to create a competitive market environment insulated from the influence of local politicians, the result can actually be more interest-group influence on privatization potentially distorting the market mechanism.

With respect to the implications for the broader public administration literature the study suggests that the influence of special interest groups should receive more scholarly attention not only for privatization decision but for many other public administration topics. These issues could be the study of reform processes (Bonesrønning 2013; Rattsø and Sørensen 2004), the budget output of public organizations (Freeman and Han 2012), the working conditions of public employees (Anzia and Moe 2015) and the cost-effectiveness of public services. In analyzing these and related issues, the study furthermore suggests that researchers pay attention to the way public authorities by their institutional choices (such as deciding between contracting out and a voucher market) can affect the influence potential of special interest groups. 
Table 1. Descriptive Statistics in 2012

\begin{tabular}{|c|c|c|c|c|c|}
\hline Variable & Observations & Mean & Std. Dev. & Min & Max \\
\hline Eldercare privatization $(\%)$ & 98 & 18.8 & 8.3 & 3.0 & 68.1 \\
\hline Union density (national average $=100$ ) & 98 & 98.6 & 12.0 & 66.0 & 118.0 \\
\hline Municipal eldercare employees (per 1,000 voters) & 98 & 23.9 & 5.3 & 11.0 & 43.2 \\
\hline Elderly spending as a share of total spending (\%) & 98 & 12.4 & 2.0 & 7.5 & 18.2 \\
\hline Fiscal stress & 98 & 0.32 & 0.04 & 0.19 & 0.39 \\
\hline Elderly over age 65 & 98 & 9,879 & 7,825 & 594 & 57,101 \\
\hline Area in $\mathrm{km}^{2}$ & 98 & 438 & 371 & 9 & 1,495 \\
\hline Small island (dummy) & 98 & 0.05 & 0.22 & 0 & 1 \\
\hline Large city above 100,000 inhabitants (dummy) & 98 & 0.07 & 0.26 & 0 & 1 \\
\hline Amalgamated in 2007 (dummy) & 98 & 0.67 & 0.47 & 0 & 1 \\
\hline Share of left-wing mandates $(\%)$ & 98 & 45.9 & 12.6 & 10.5 & 78.9 \\
\hline Share of left-wing mandates in 2011 national election (\%) & 99 & 39.4 & 7.7 & 15.8 & 61.3 \\
\hline District organization (dummy) & 98 & 0.43 & 0.50 & 0 & 1 \\
\hline Municipal costs per hour (DKK) & 96 & 417 & 48 & 290 & 576 \\
\hline Number of private contractors & 98 & 9.8 & 6.2 & 1 & 32 \\
\hline Vote share of elderly over age $65(\%)$ & 98 & 24.5 & 3.7 & 12.6 & 37.0 \\
\hline Average eldercare privatization in neighboring municipalities (\%) & 98 & 19.2 & 5.7 & 3.0 & 45.3 \\
\hline Weighted average union density in neighboring municipalities & 98 & 98.7 & 11.1 & 69.5 & 114.6 \\
\hline
\end{tabular}

Note: See variable definitions and sources in Appendix 1 
Table 2. The Effect of Union Strength and the Number of Municipal Eldercare Workers on Privatization, $2012(\mathrm{~N}=98)$

\begin{tabular}{|c|c|c|c|c|c|c|c|c|}
\hline & $\begin{array}{l}\text { (1) } \\
\text { Privatizati } \\
\text { on } \\
\end{array}$ & $\begin{array}{l}\text { (2) } \\
\text { Privatizati } \\
\text { on } \\
\end{array}$ & $\begin{array}{l}\text { (3) } \\
\text { Privatizati } \\
\text { on }\end{array}$ & $\begin{array}{l}\text { (4) } \\
\text { Privatizati } \\
\text { on }\end{array}$ & $\begin{array}{l}\text { (5) } \\
\text { Privatizati } \\
\text { on }\end{array}$ & $\begin{array}{l}\text { (6) } \\
\text { Privatizati } \\
\text { on }\end{array}$ & $\begin{array}{l}\text { (7) } \\
\text { Privatizati } \\
\text { on }\end{array}$ & $\begin{array}{l}\text { (8) } \\
\text { Privatizati } \\
\text { on }\end{array}$ \\
\hline \multicolumn{9}{|l|}{ Public employees } \\
\hline Union density (national average $=100$ ) & $\begin{array}{l}-0.302 * * * \\
(-4.03)\end{array}$ & $\begin{array}{l}-0.218 * * \\
(-2.59)\end{array}$ & $\begin{array}{l}-0.237 * * \\
(-2.13)\end{array}$ & $\begin{array}{l}-0.239 * * \\
(-2.15)\end{array}$ & $\begin{array}{l}-0.250 * * \\
(-2.23)\end{array}$ & $\begin{array}{l}-0.251 * * \\
(-2.29)\end{array}$ & $\begin{array}{l}-0.176^{*} \\
(-1.90)\end{array}$ & $\begin{array}{l}-0.207^{*} \\
(-1.67)\end{array}$ \\
\hline $\begin{array}{l}\text { Municipal eldercare employees (per 1,000 } \\
\text { voters) }\end{array}$ & & & & & & & $\begin{array}{l}-0.792 * * \\
(-2.53)\end{array}$ & \\
\hline $\begin{array}{l}\text { Elderly spending as a share of total spending } \\
(\%)\end{array}$ & & & & & & & & $\begin{array}{l}-0.592 \\
(-1.34)\end{array}$ \\
\hline \multicolumn{9}{|l|}{ Fiscal stress } \\
\hline Fiscal stress (in 100) & & $\begin{array}{l}-0.374 \\
(-1.51)\end{array}$ & $\begin{array}{l}-0.409 \\
(-1.56)\end{array}$ & $\begin{array}{l}-0.390 \\
(-1.59)\end{array}$ & $\begin{array}{l}-0.653 * * \\
(-2.45)\end{array}$ & $\begin{array}{l}-0.587 * * \\
(-2.04)\end{array}$ & $\begin{array}{l}-0.339 \\
(-1.40)\end{array}$ & $\begin{array}{l}-0.680^{* * *} \\
(-2.47)\end{array}$ \\
\hline \multicolumn{9}{|l|}{ Scale and market structure } \\
\hline Elderly over age $65(\log )$ & & & $\begin{array}{l}0.138 \\
(0.17)\end{array}$ & $\begin{array}{l}-2.417 \\
(-1.49)\end{array}$ & $\begin{array}{l}-3.000 * \\
(-1.86)\end{array}$ & $\begin{array}{l}-2.798^{*} \\
(-1.67)\end{array}$ & $\begin{array}{l}-2.291 * \\
(-1.68)\end{array}$ & $\begin{array}{l}-2.467 \\
(-1.61)\end{array}$ \\
\hline Area in $\mathrm{km}^{2}(\log )$ & & & $\begin{array}{l}0.369 \\
(0.46)\end{array}$ & $\begin{array}{l}0.650 \\
(0.81)\end{array}$ & $\begin{array}{l}1.728^{*} \\
(1.91)\end{array}$ & $\begin{array}{l}1.288 \\
(1.62)\end{array}$ & $\begin{array}{l}1.464^{*} \\
(1.75)\end{array}$ & $\begin{array}{l}1.537 \\
(1.65)\end{array}$ \\
\hline Small island (dummy) & & & & $\begin{array}{l}-7.694 * * \\
(-2.37)\end{array}$ & $\begin{array}{l}-5.698 \\
(-1.59)\end{array}$ & $\begin{array}{l}-8.064 * * \\
(-2.42)\end{array}$ & $\begin{array}{l}3.311 \\
(0.64)\end{array}$ & $\begin{array}{l}-3.767 \\
(-1.10)\end{array}$ \\
\hline Large city (dummy) & & & & $\begin{array}{l}4.570^{*} \\
(1.96)\end{array}$ & $\begin{array}{l}4.030 \\
(1.64)\end{array}$ & $\begin{array}{l}4.298^{*} \\
(1.78)\end{array}$ & $\begin{array}{l}1.297 \\
(0.64)\end{array}$ & $\begin{array}{l}3.437 \\
(1.44)\end{array}$ \\
\hline \multicolumn{9}{|l|}{ Public preferences } \\
\hline Amalgamated in 2007 (dummy) & & & & & $\begin{array}{l}-1.143 \\
(-0.51)\end{array}$ & $\begin{array}{l}-0.667 \\
(-0.28)\end{array}$ & $\begin{array}{l}-0.789 \\
(-0.39)\end{array}$ & $\begin{array}{l}-0.876 \\
(-0.40)\end{array}$ \\
\hline Share of left-wing mandates (\%) & & & & & $\begin{array}{l}0.115^{*} \\
(1.81)\end{array}$ & & $\begin{array}{l}0.0721 \\
(1.10)\end{array}$ & $\begin{array}{l}0.0824 \\
(1.13)\end{array}$ \\
\hline $\begin{array}{l}\text { Share of left-wing mandates in national } \\
\text { election }(\%)\end{array}$ & & & & & & $\begin{array}{l}0.108 \\
(0.91)\end{array}$ & & \\
\hline Constant & $\begin{array}{l}48.61 \text { *** } \\
(6.22)\end{array}$ & $\begin{array}{l}52.06 * * * \\
(5.94)\end{array}$ & $\begin{array}{l}51.79 * * * \\
(3.59)\end{array}$ & $\begin{array}{l}\text { 72.91**** } \\
(3.88)\end{array}$ & $\begin{array}{l}77.03 * * * \\
(4.02)\end{array}$ & $\begin{array}{l}76.43 * * * \\
(4.05)\end{array}$ & $\begin{array}{l}75.24 * * * \\
(4.52)\end{array}$ & $\begin{array}{l}78.49 \text { **** } \\
(4.07)\end{array}$ \\
\hline $\mathrm{N}$ & 98 & 98 & 98 & 98 & 98 & 98 & 98 & 98 \\
\hline $\mathrm{r} 2$ & 0.191 & 0.207 & 0.209 & 0.235 & 0.251 & 0.239 & 0.386 & 0.264 \\
\hline $\mathrm{F}$ & 16.26 & 8.090 & 5.338 & 8.529 & 6.423 & 7.096 & 5.795 & 5.921 \\
\hline Estimation method & OLS & OLS & OLS & OLS & OLS & OLS & OLS & OLS \\
\hline Time period & 2012 & 2012 & 2012 & 2012 & 2012 & 2012 & 2012 & 2012 \\
\hline
\end{tabular}

Note: OLS estimations with robust standard errors. * significance level $0.10, * *$ significance level $0.05, * * *$ significance le vel 0.01. t-statistics in brackets. 


\section{APPENDIX 1: MEASUREMENT OF VARIABLES}

Table 3. Measurement and Data Sources of Variables, 2012

\begin{tabular}{|c|c|}
\hline Variable & Operationalization and data source \\
\hline Eldercare privatization $(\%)$ & $\begin{array}{l}\text { Share of services performed by private suppliers within the eldercare sector. Main function } 5.32 \text { in the municipal accounting } \\
\text { system, which in } 2012 \text { covered } 23.0 \% \text { of all services eligible for private contracting. Source: Local Government Denmark } \\
\text { (LGDK). }\end{array}$ \\
\hline $\begin{array}{l}\text { Union density (national average }= \\
100 \text { ) }\end{array}$ & $\begin{array}{l}\text { The number of municipal employees within eldercare who are also FOA members as a share of all municipal employees } \\
\text { within eldercare, October } 1^{\text {st }} 2012 \text {. Index } 100 \text {. }\end{array}$ \\
\hline & $\begin{array}{l}\text { In technical terms, the variable is measured as the number of FOA members employed under FOA's agreement with Local } \\
\text { Government Denmark (LGDK) for social and health assistants as a share of all of the municipal employees under this } \\
\text { agreement (index 100). The agreement covers various types of social and health assistants, including social and health } \\
\text { assistants, nursing aides, nursing home assistants, personal care workers, employment counsellors and social and health } \\
\text { trainees. Source: FOA. }\end{array}$ \\
\hline
\end{tabular}

Municipal eldercare employees (per Municipal employees under the agreement for social and health care workers and the agreement for nursing and health care 1,000 voters) $\quad$ workers as a share of people over age 18 (per 10,000). Source: The Municipalities' and Counties' Salary Data Office and Local Government Denmark (LGDK).

Elderly spending as a share of total Net spending on eldercare as a share of total net operating expenditures in $\%$. The definition of elderly spending follows the spending $(\%)$ same definition Local Government Denmark (LGDK) and the national government agreed upon in 2012 (http://www.kl.dk/Fagomrader/Okonomi-og-dokumentation/Kommunale-udgiftsomrader/Serviceudgifter/). Operating expenditures include all of the net expenditures excluding capital investments and transfers. Source: Statistics Denmark.

Fiscal stress

Total demographic and socioeconomic expenditure needs relative to the financial base of the municipalities. Expenditure needs are estimated according to the objective criteria in the Equalization Scheme. The financial base is calculated as the tax base from income and property taxes plus a government grant (that equalizes some of the financial differences between the municipalities). Source: The Municipal Key Figures, The Ministry of Economic Affairs and the Interior.

Elderly over age 65

The number of people over age 65 in the municipality as of January 1. Source: The Municipal Key Figures, The Ministry of Economic Affairs and the Interior.

Area in $\mathrm{km}^{2}$

The geographical area of the municipality in $\mathrm{km}^{2}$. Source: The Municipal Key Figures, The Ministry of Economic Affairs and the Interior.

Small island

Dummy for five small island municipalities.

Large city above 100,000 inhabitants Dummy for municipalities with more than 100,000 inhabitants as of January 1 .

(dummy)

Amalgamated in 2007 (dummy)

Dummy assigned the value 1 to all 66 amalgamated municipalities ( 0 for 32 non-amalgamated municipalities)

Share of left-wing mandates $(\%)$

Number of socialist seats in the city council as a percentage of all seats. The following parties are coded as being socialist: Social Democrats, Socialist People’s Party, Red-Green Alliance. Source: KMD Election Archive.

Share of left-wing mandates in 2011 The share of socialist voters in the municipality in the national election in 2011 in $\%$. The following parties are coded as being national election $(\%)$ socialist: Social Democrats, Socialist People’s Party, Red-Green Alliance. Source: The Danish Election Database.

District organization (dummy)

Dummy for municipalities with more than one district within the eldercare sector, October 1, 2012. Source: The Free Choice Data Base, The Directorate of Social Services.

Municipal costs per hour (DKK)

Price per hour for practical help in DKK, October 1, 2012. Source: The Free Choice Data Base, The Directorate of Social Services.

Number of private contractors

Number of approved private contractors for practical help, October 1, 2012. Source: The Free Choice Data Base, The Directorate of Social Services.

Vote share of elderly over age $65(\%)$ The number of people over age 65 as a share of all municipal inhabitants over age 18 as of January 1 . Source: The Municipal Key Figures, The Ministry of Economic Affairs and the Interior.

Average eldercare privatization in Average eldercare privatization in the municipalities sharing a border with the municipality. For the five small islands that neighboring municipalities (\%) do not share borders with any other municipality, the variable refers to the eldercare privatization in the municipalities to which a ferry runs. Source: Local Government Denmark (LGDK).

Weighted average union density in The average union density in the municipalities sharing a border with the municipality. This union density average of the neighboring municipalities $(\%)$ surrounding municipalities is weighted by the spending on eldercare in the surrounding municipalities. For the five small
islands that do not share borders with any other municipality, the instrument refers to the union density in the municipalities to which a ferry runs. Source: FOA. 


\section{REFERENCES}

Amirkhanyan, Anna A. 2006. The smart-seller challenge: Exploring the determinants of privatizing public nursing homes. Journal of Public Administration Research \& Theory 17(3):501-27.

Andrews, Rhys. 2013. Local government size and efficiency in labor-intensive public services: Evidence from local educational authorities in England. In The challenge of local government size, ed. Santiago Lago-Penas and Jorge Martinez-Vazguez, Cheltenham, UK. Edward Elgar.

Anzia, Sarah F., and Terry M. Moe. 2015. Public sector unions and the costs of government. Journal of Politics (forthcoming).

Bækgaard, Martin. 2011. Frit valg i aeldreplejen [Free choice in the eldercare sector]. Aarhus: Krevi.

Bailey, Stephen J. 1999. Local government economics. Principles and practice. London: Macmillan.

Bel, Germa. 2013. Local government size and effciency in capital-intensive services: What evidence is there of economies of scale, density and scope? In The challenge of local government size, ed. Santiago Lago-Penas and Jorge Martinez-Vazguez, Cheltenham, UK. Edward Elgar.

Bel, Germa, Trevor Brown, and Mildred Warner. 2014. Editorial overview: Symposium on mixed and hybrid models of public service delivery. International Public Management Journal 17(3):297307. doi: 10.1080/10967494.2014.935231.

Bel, Germa, and Xavier Fageda. 2007. Why do local governments privatise public services? Local Government Studies 33(4):517-34.

2009. Factors explaining local privatization: A meta-regression analysis. Public Choice 139:10519.

Bhatti, Yosef, and Kasper M. Hansen. 2013. Public employees lining up at the polls: The conditional effect of living and working in the same municipality. Public Choice 156:611-29.

Bhatti, Yosef, Asmus Leth Olsen, and Lene Holm Pedersen. 2009. The effects of administrative professionals on contracting out Governance: An International Journal of Policy, Administration and Institutions 22(1):121-37.

Böhlmark, Anders, and Mikael Lindahl. 2007. The impact of school choice on pupil achievement, Segregation and costs: Swedish evidence. In IZA Discussion Papers. Bonn, Germany: Institute for the Study of Labor (IZA).

Bonesrønning, Hans. 2013. Public employees and public sector reform implementation. Public Choice (156):309-27.

Boyne, George A. 1998. The determinants of variations in local service contracting: Carbage in, garbage out? Urban Affairs Review 34(1):150-63.

Brown, Trevor, and Matthew Potoski. 2003. Transaction costs and institutional explanations for government service production decisions. Journal of Public Administration Research and Theory 13(4):441-68.

Campbell, Andrea Louise, and Michael W. Sances. 2013. State fiscal policy during the Great Recession: Budgetary impacts and policy response. The Annals of the American Academy of Political and Social Science 650 (252-73).

Chandler, Timothy D., and P. Feuille. 1991. Municipal unions and privatization. Public Administration Review 51(1):15-22.

- 1994. Cities, unions and the privatization of sanitation services. Journal of Labor Research $\mathrm{XV}(1): 53-71$.

Christoffersen, Henrik, and Martin Paldam. 2003. Markets and municipalities: A study of the behavior of the municipalities. Public Choice 114:79-102.

Domberger, Simon, and Paul Jensen. 1997. Contracting out by the public sector: Theory, evidence, prospects. Oxford Review of Economic Policy 13(4):67-78.

Elinder, Mikael, and Henrik Jordahl. 2013. Political preferences and public sector outsourcing. European Journal of Political Economy 30:43-57. 
Fernandez, Sergio, Jay Eungha Ryu, and Jeffrey L. Brudney. 2008. Exploring variations in contracting for services among American local governments: Do politics still matter? The American Review of Public Administration 38(4):439-62. doi: 10.1177/0275074007311386.

Ferris, James M. 1986. The decision to contract out: An empirical analysis. Urban Affairs Review 22(2):289-11. doi: 10.1177/004208168602200206.

FOA. 2013a. Rundspørge blandt ældrechefer om tilsyn med private leverandører på ældreområdet [Survey among eldercare managers about the supervisory control with private contractors within the eldercare sector].

—. 2013b. Stop skruppelløse plejefirmaer [Stop dishonest care firms]. Accessed 15 January 2015. http://www.foa.dk/forbund/nyheder?newsid=27cff6e1-85c1-49e0-822f-0ebd09b6715c.

_. 2015a. FOA erklærer krig mod plejefirma [FOA annonces war on care firm]. Accessed 23 February 2015. http://www.foa.dk/Forbund/Nyheder?newsid=3BC28FFF-C6B1-41E6-943DD75B2F1283E6.

—. 2015b. FOAs historie [FOA's history]. Accessed 18 February 2015. http://www.foa.dk/Forbund/Om-FOA/FOAs-historie.

Foged, Søren Kjær. 2015a. Årsager til konkurrenceudsættelse i danske kommuner, 2007-2013: Fra generelle til sektorafhængige forklaringer [The reasons for contracting out in Danish municipalities, 2007-2013: From generic to sector-dependent explanations] Politica 47(1):24-45. . 2015b. The relationship between population size and contracting out public services: Evidence from a quasi-experiment in Danish municipalities. Urban Affairs Review Published online before print July 5:1-43. doi: 10.1177/1078087415591288.

Foged, Søren Kjær, and Kurt Houlberg. 2015. Frit valg under godkendelsesmodellen på hjemmehjælpsområdet 2008-2013: Effekter på de kommunale timepriser [Free choice for home care under the approval model 2008-2013: The effects on municipalities' hourly fees]. Roskilde: Roskilde University.

Freeman, Richard B., and Eunice Han. 2012. The war against public sector bargaining in the US. Journal of Industrial Relations 54(3):386-408.

Girth, Amanda M., Amir Hefetz, Jocelyn M. Johnston, and Mildred E. Warner. 2012. Outsourcing public service delivery: Management responses in noncompetitive markets. Public Administration Review 72(6):887-900. doi: 10.11/j.1540-6210.2012.02596.x.

Guardiola, Jorge, Fransico Gonzalez Gomez, and Miguel A. Garcia Rubio. 2010. Is time really important for research into contracting out public services in cities? Evidence for urban water management in Southern Spain. Cities 27(5):369-76.

Hebdon, Robert, and Patrice Jalette. 2008. The restructuring of municipal services: A Canada-United States comparison. Environment and Planning C:Government and Policy 26:144-58.

Hefetz, Amir, and Mildred Warner. 2004. Privatization and its reverse: Explaining the dynamics of the government contracting process. Journal of Public Administration Research \& Theory 14(2):171-90. doi: 10.1093/jopart/muh012.

- 2012. Contracting or public delivery? The importance of service, market, and management characteristics. Journal of Public Administration Research and Theory 22:289-317.

Hipp, Lena, and Mildred E. Warner. 2008. Market forces for the unemployed? Training vouchers in Germany and the USA. Social Policy \& Administration 42(1):77-101.

Hirsch, Werner Z. 1995. Factors important in local governments' privatization decision. Urban Affairs Quarterly 31(November 1995):226-63.

Hirsch, Werner Z., and Even Osborne. 2000. Privatization of government services: Pressure-group resistance and service transparency. Journal of Labor Research 21(2):315-26.

Hodge, Graeme A. 1998. Contracting public sector services: A meta-analytic perspective of the international evidence. Australian Journal of Public Administration 57(4):98-110.

Iversen, Torben, and David Soskice. 2015. Information, inequality, and mass polarization: Ideology in advanced democracies. Comparative Political Studies Published online before print:1-33. 
Jalette, Patrice, and Robert Hebdon. 2012. Unions and privatization: Opening the "black box". Industrial \& Labor Relations Review 65(1):17-35.

Jensen, Jason L., Paul E. Sum, and David T. Flynn. 2009. Political orientations and behavior of public employees: A cross-national comparison. Journal of Public Administration Research and Theory: J-PART 19(4):709-30.

King, Gary, Robert Keohane, and Sidney Verba. 1994. Designing social inquiry. Princeton, NJ: Princeton University Press.

Levin, Jonathan, and Steven Tadelis. 2010. Contracting for government services: Theory and evidence from U.S. cities. The Journal of Industrial Economics LVIII (3):507-41.

Lowery, David. 1998. Consumer sovereignty and quasi-market failure. Journal of Public Administration Research \& Theory 8(2):137-72.

Olson, Mancur Jr. 1965. The logic of collective action. New York: Schocken Books.

Pallesen, Thomas. 2004. A political perspective on contracting out: The politics of good times: Experiences from Danish local governments. Governance 17(4):573-87.

Petersen, Ole Helby, Kurt Houlberg, and Lasse Ring Christensen. 2015. Contracting out local services: A tale of technical and social services. Public Administration Review 75(4):560-70.

Petersen, Ole Helby, and Ulf Hjelmar. 2014. Marketization of welfare services in Scandinavia: A review of Swedish and Danish experiences. Scandinavian Journal of Public Administration 17(4):3-20.

Rattsø, Jørn, and Rune J. Sørensen. 2004. Public Employees as Swing Voters: Empirical Evidence on Opposition to Public Reform. Public Choice 119:281-310.

Rostgaard, Tine. 2006. Constructing the care consumer: Free choice of home care for the elderly in Denmark. European Societies 8(3):443-63.

Sandström, F. Mikael, and Fredrik Bergström. 2005. School vouchers in practice: Competition will not hurt you. Journal of Public Economics 89(2-3):351-80. doi: http://dx.doi.org/10.1016/i.jpubeco.2004.03.004.

Savas, Emanuel. 1987. Privatization: The key to better government. Chatham, NJ: Chatham House.

Shrestha, Manoj K., and Richard C. Feiock. 2011. Transaction cost, exchange embeddedness, and interlocal cooperation in local public goods supply. Political Research Quarterly 64(3):573-87. doi: $10.2307 / 23056376$.

Stolt, Ragnar, Paula Blomquist, and Ulrika Winblad. 2011. Privatization of social services: Quality differences in Swedish elderly care. Social Science \& Medicine (72):560-67.

Sundell, Anders, and Victor Lapuente. 2012. Adam Smith or Machiavelli? Political incentives for contracting out local public services. Public Choice 153(3-4):469-85.

Tepe, Markus. 2012. The public/private sector cleavage revisited: The impact of government employment on political attitudes and behaviour in 11 West European countries. Public Administration 90(1):230-61. doi: 10.1111/j.1467-9299.2011.01961.x.

Vrangbæk, Karsten, Ole Helby Petersen, and Ulf Hjelmar. 2015. Is contracting out good or bad for employees? A review of international experience. Review of Public Personnel Administration 35(1):3-23.

Warner, Mildred E. 2013. Does local government size matter? Privatization and hybrid systems of local service delivery. In The Challenge of Local Government Size, ed. Santiago Lago-Penas and Jorge Matinez-Vazguez, Cheltenham, UK. Edwar Elgar.

Warner, Mildred E., and Raymond H. J. M. Gradus. 2011. The consequences of implementing a child care voucher scheme: Evidence from Australia, the Netherlands and the USA. Social Policy \& Administration 45(5):569-92.

Warner, Mildred E., and Robert Hebdon. 2001. Local government restructuring: Privatization and its alternatives. Journal of Policy Analysis and Management 20(2):315-36. 